\title{
Connection Between Civil Public Interest Litigation of Social Organizations and Environmental Administrative Law Enforcement
}

\author{
Ganping Wang ${ }^{1, a}$ \\ ${ }^{1}$ School of law and Humanities and society, Wuhan University of Technology, Wuhan, Hubei, China \\ a978582826@qq.com
}

\begin{abstract}
As one of the subjects of environmental civil public interest litigation, social organizations play an important role in the environmental civil public interest litigation system.As the representative organ of China's environmental public interests or other departments responsible for the supervision and administration of environmental protection, the environmental administrative law enforcement department shall safeguard the environmental public interests according to law. In the practice of the two systems, there are not exhaustive administrative law enforcement before litigation and misplaced responsibilities; Judicial activism in litigation, waste of resources and overlapping legal responsibilities after litigation. Social organizations should establish a legal and effective connection with the environmental administrative law enforcement system before filing environmental civil public interest litigation. By analyzing the relevant theories, the author clarifies the functional orientation and relationship between the two, analyzes and draws lessons from the advanced experience of various countries, and puts forward specific improvement measures, including establishing the contact mechanism of administrative law enforcement; Optimize the pre-litigation procedure and establish a public participation mechanism.
\end{abstract}

Keywords: Social organization, Environmental civil public interest litigation, Environmental administrative law enforcement, Cohesion Mechanism.

\section{INTRODUCTION}

On May 28, 2020, the third session of the 13th National People's Congress voted and adopted the civil code of the people's Republic of China, which will come into force on January 1, 2021. The tort liability part of the civil code continues to adopt a special chapter to stipulate the liability for environmental pollution and ecological damage in seven articles of articles 1229-1235, and further improve and refine the liability concept, scope, mode and degree of environmental tort. It can be seen that environmental civil public interest litigation plays an important role in combating environmental tort and maintaining environmental public interest. As one of the important initiating subjects of the litigation procedure, social organizations play an important role.

Since the revision of the environmental protection law and the promulgation of the judicial interpretation in 2015, many environmental cases have environmental administrative law enforcement first, and social organizations lack effective communication and connection with relevant administrative organs before filing environmental civil public interest litigation, resulting in many problems in practice, such as functional dislocation, resource waste and low efficiency, which affect the effective exertion of their due functions, It also inhibits the realization of the due effect of the environmental civil public interest litigation mechanism. Based on this, this paper makes an in-depth study on the purpose, orientation and function of the environmental civil public interest litigation system of social organizations, so as to enrich and improve the connection mechanism between environmental civil public interest litigation filed by social organizations and environmental administrative law enforcement.

\section{PROBLEM RAISING}

In order to fully understand the application of social organization prosecution system in environmental civil 
public interest litigation, the author uses "public interest litigation" and "social organization" and the search time from 2015 to 2020 under "China judicial document network" and "civil litigation causes".Due to the singleness of data source and the timeliness of data update, these data statistics can not guarantee accuracy, but can roughly reflect the relevant situation of social organization litigation system in environmental civil public interest litigation.On the one hand, the number of environmental civil public interest litigation cases filed by social organizations has increased year by year, including 6 in 2015, 21 in 2016, 27 in 2017, 48 in 2018, 84 in 2019 and 121 in 2020.On the other hand, according to rough statistics, there are about 30 social organizations that have filed more than one public interest litigation, with litigation cases from 2015 to 2019. Environmental civil public interest cases are on the rise, and the number of social organizations filing public interest litigation is increasing.

\subsection{The administrative law enforcement is not exhausted before litigation, and the duties are misplaced}

From the perspective of environmental administration, administrative organs have the advantages of high efficiency, professionalism and flexibility. The scope of environmental administration is expanding day by day and has become the main force of eco-environmental damage relief. Eco-environmental problems are becoming increasingly prominent. The development of environmental administration also shows the characteristics of governance scope from maintaining social order to risk supervision, and operation mode from passive to active.

From the perspective of environmental justice, justice mainly solves the application of law. Environmental justice can give full play to its initiative and become the help of ecological environment damage relief. Positive justice plays an important role in rebuilding social order, alleviating social contradictions and balancing social contradictions. It pays attention to the interests of all parties and innovates social management.

However, in practice, although social organizations enjoy superficial representation in the environmental civil public interest litigation system, their role is mainly reflected in the filing of environmental civil public interest litigation, but they play little role in the litigation process, mainly because the litigation timeliness of environmental cases is poor. In environmental civil public interest litigation, plaintiffs are often not "professional" and "focused""In contrast, it is more convenient and effective for the government to deal with such cases with clear facts, obvious damage and simple relationship.[1]

\subsection{Judicial activism in litigation wastes resources}

For the handling of cases, the environmental law enforcement department can only provide reference opinions according to the requirements of the court. It has no initiative and suggests "reference"The effect is not obvious; the environmental administrative department has no right to intervene in mediation, reconciliation or cancellation of litigation; the environmental administrative department has no obligation and responsibility to cooperate with the execution of the judgment. The resulting situation is that in the process of case trial, the judicial organ without professional advantages racked its brains to make various technical judgments, while the regulatory department, as a professional institution, "Implement unified supervision and administration of environmental protection within their respective administrative areas". $\mathrm{He}$ is often in a passive and lazy state. In the process of execution, the lack of regulators leads to the fact that the effective date of the judgment is often the time when the court is in trouble - the disposal of winning funds, the performance of maintenance responsibilities, the evaluation of execution effect, acceptance and follow-up supervision all require huge costs, which are not the president of the court, but local governments and relevant departments that "should be responsible for the environmental quality of their administrative regions" enjoy success that has nothing to do with anything. This dislocation of responsibilities between judicial organs and administrative organs not only wastes resources of all parties, but also deviates from their respective responsibilities and identities, which is not conducive to the overall division of labor, coordination and complementarity of environmental governance.

Because regulators have neither the right to intervene in public interest litigation nor the responsibility to cooperate with the execution, the trial and execution are almost entirely undertaken by the court. Many factual and technical problems are directly handled by judges who do not have professional ability, which not only wastes judicial resources, but also can not ensure authority and efficiency.[2]

\subsection{Overlapping legal liabilities after litigation}

The functional overlap between environmental public interest litigation and environmental administrative law enforcement is mainly reflected in the functional overlap of relief responsibility. At present, there are three main ways of liability relief in environmental administrative law enforcement: one is to order compensation for losses, the other is to restore the damaged ecological environment and natural resources, and the third is to order payment of disposal fees. 
In environmental civil public interest litigation, the liability mode of ordering to stop infringement, restore the original state and compensate for losses overlaps or even conflicts with the liability mode of environmental administrative law enforcement. On the one hand, when the environmental protection department makes an effective punishment first and the court makes a similar treatment on the same matter, it leads to repeated law enforcement. On the other hand, when the current system is not perfect, it will lead to the conflict between litigation and law enforcement, which should be parallel. In case of conflict or repetition with environmental administrative law enforcement, it will not only affect the public determination of environmental administrative law enforcement, but also damage the authority of law.[3]

\section{ANALYSIS OF THE CAUSES OF THE PROBLEM}

\subsection{The construction of civil public interest litigation system lacks sufficient legal basis}

Under the influence of tort litigation theory, China's environmental civil public interest litigation system is completely designed from the perspective of property relief. As long as damage is caused, various liability means can be used comprehensively, without distinguishing between behavior correction and damage filling. In essence, subrogation law enforcement litigation and ecological damage filling litigation are confused, resulting in a lot of confusion and dislocation.[4]

\subsection{Environmental administrative law enforcement departments do not fully perform their duties}

The fundamental reason for the incomplete performance of environmental administrative law enforcement departments lies in the lack of legal liability provisions, that is, the legislation does not establish a form of liability with the function of making up for damage. The solution lies in improving environmental legislation, establishing a public legal ecological damage repair and compensation system, and clearly giving law enforcers the power and responsibility to investigate such liability, rather than starting a new stove.In the case of substantive law, it is directly implemented by ordinary subjects through the so-called civil litigation.[5]

\section{THE CONSTRUCTION OF COHENSHION SYSTEM}

\subsection{Establish a law enforcement contact mechanism}

Fully respect the responsibilities of environmental protection authorities and other environmental protection supervision and administration departments to safeguard environmental public interests, and take the environmental public interest litigation system as a supplement to the responsibilities of environmental protection authorities and other environmental protection supervision and administration departments to safeguard environmental public interests.[6]

First, priority should be given to law enforcement before litigation. The interpretation of environmental civil public interest litigation requires the court to notify the regulatory authorities immediately after receiving the prosecution materials. If no law enforcement action is taken within the time limit, there should be a reasonable time limit for formal filing. The second is to establish a trial consultation and consultation mechanism, so that the regulatory authorities can participate in the litigation more conveniently and directly, and provide professional case handling opinions. The third is to implement the division of labor, clarify the role of regulatory authorities in scheme formulation and decision-making, clarify the obligations and responsibilities in process supervision, acceptance and evaluation, give full play to their professional advantages and promote them to effectively bear legal responsibilities.[7]

\subsection{Optimization of pretrial procedure environmental civil public interest litigation.}

Pre-litigation procedure means that the subject of litigation shall not seek relief through judicial channels before applying for specific internal or administrative relief. When constructing the environmental civil public interest litigation system, we should clearly stipulate the pre-procedure of bringing environmental civil public interest litigation, and respect the responsibility of environmental administrative supervision and management institutions to safeguard environmental public interests. At present, China has only established the "pre litigation procedure" of public interest litigation with the procuratorial organ as the prosecution subject, mainly including the pre performance supervision procedure and support prosecution procedure of civil public interest litigation, as well as the pre-performance supervision procedure of administrative public interest litigation. For the civil public interest litigation system of social organizations, only pre-litigation notice and cancellation procedures are stipulated. The single provision of pre-litigation notice and cancellation does not really realize the principle of administrative priority and litigation openness.[8]

Therefore, the pre-procedure for social organizations to file environmental public interest litigation should be clearly stipulated, and the administrative priority of administrative organs should be fully respected. We can learn from the experience of American civil litigation 
system.First of all, before filing an environmental civil public interest lawsuit, the social organization shall notify the competent administrative organ in charge of environmental supervision in writing of the results of the damage to the ecological environment and the defendant's illegal acts, and take specific measures to solve them.If the competent environmental administrative organ fails to solve the problem within the time limit, a social organization may bring a lawsuit.Secondly, according to the matching degree between environmental administrative law enforcement and civil public interest litigation claims of social organizations, this paper makes a fine design to eliminate the concurrence of the two liability modes. The social organization's application for withdrawal is based on the relevant administrative departments' performance of environmental supervision duties according to law, so that the plaintiff's requirements can be fully realized, and the people's court shall grant permission.If a social organization insists on not applying for withdrawal, the people's court shall reject the appeal.If the litigation claims of social organizations are partially realized due to the relevant administrative departments performing their duties of environmental supervision according to law, the people's court may make a judgment on the unrealized claims.If the relevant administrative department refuses to perform its environmental supervision duties or fails to perform its corresponding environmental supervision duties, resulting in the failure to meet the requirements of the social organization, the social organization may conduct a complete environmental public interest litigation procedure.[9]

\subsection{Establish a public participation mechanism}

The real owner of environmental public welfare is the interested public. Therefore, litigation should enhance the democracy and legitimacy of decision-making through the interested public participation, and listening to the public's opinions can also enhance the rationality of the treatment results. At present, Article 16 of the people's jury law, Article 23 of the interpretation of environmental civil public interest litigation and Article 25 of the interpretation of environmental civil public interest litigation have relevant provisions on public participation, which still need to be further improved and optimized.

Therefore, in the process of environmental administrative law enforcement, law enforcement methods and measures should ensure full public participation, so that stakeholders can effectively exert a practical impact on the treatment results of natural resource damage. In addition, when entering the procedure of litigation relief, the public also needs to comment on the formulation, selection and implementation of the restoration plan.[10]

\section{CONCLUSIONS}

Between the system of environmental civil public interest litigation brought by social organizations and the system of environmental administrative law enforcement, there are endless administrative law enforcement before litigation and dislocation of responsibilities; Judicature in litigation is too active and wastes resources; On the one hand, the legal provisions of civil public interest litigation of social organizations are insufficient, resulting in the unclear functional positioning of environmental judicial power and environmental administrative power. On the other hand, the environmental administrative organs do not fully perform their duties in environmental administrative law enforcement. It is necessary to establish a contact mechanism for environmental administrative law enforcement to explore and solve the above problems by learning from foreign successful experience; Optimizing the pretrial procedure of environmental civil public interest litigation; And improve and optimize the public participation mechanism.

\section{REFERENCES}

[1] Qin, T. B.(2020) Supporting prosecution in environmental civil public interest litigation. J. Administrative law, No.6.

[2] Xue,Y.H.(2020)The conflict and resolution between environmental public interest litigation and environmental administrative law enforcement. J. China soft science, No.4.

[3] Gong, X. D.(2019) Repeated liability in environmental civil public interest litigation after public law sanctions -- Taking Xiangsheng company case as an example.J.Administrative law, No. 5.

[4] Zhang,X.Y.(2020)Identification of "failure to perform duties according to law" in administrative public interest litigation.J. Zhejiang Social Sciences, No.1.

[5] Wang,Q.J.(2020)Review basis of administrative omission in environmental administrative public interest litigation,.J.Tsinghua law, issue 2.

[6] Yu, W. X., Yang,S.N(2019).The pre-litigation procedure of environmental administrative public interest litigation.J. China applied law, No. 1.

[7] Lin,W.X.(2014)Discussion on environmental civil public interest litigation disputes.J. Application of law,No.10.

[8] ]Wang Jingbo.(2015)Three theoretical issues of environmental administrative litigation.J.People's Justice,Issue 6. 
[9] Wang,L.M.(2021)Highlights of the responsibility for environmental pollution and ecological damage in the civil code. Guangdong Social Sciences, issue 1.
[10] Gong,G.(2019) Reflection on the nature of environmental civil public interest litigation.J.legal research, issue 3 . 